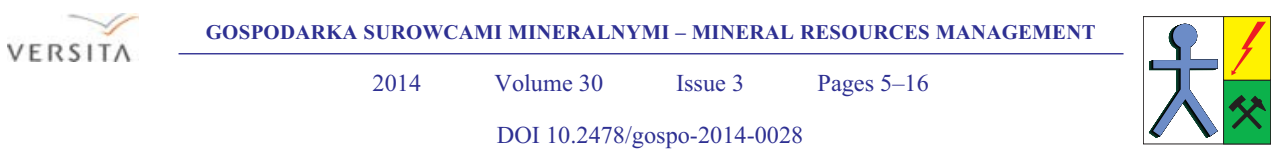

\title{
Quality of Zeolite in the Function of Size Class
}

\section{Introduction}

The influence of sized zeolite product range on the ability of adsorption has been studied by numerous researchers. Research in this area has mostly concentrated on natural zeolite, production results that can be used in the application of zeolite products for animal feed or water purification. Researchers use the following range of size classes for this purpose: powder, $-5+2 \mathrm{~mm},-2+0.5 \mathrm{~mm},-2+0 \mathrm{~mm},-2.4+1.4 \mathrm{~mm},-1.4+0.4 \mathrm{~mm},-0.4+0 \mathrm{~mm}$, $-0.1+0 \mathrm{~mm},-0.8+0.6 \mathrm{~mm},-0.5+0 \mathrm{~mm},-0.5+0.315 \mathrm{~mm},-0.15+0.075 \mathrm{~mm},-0.090$ $+0.063 \mathrm{~mm},-0.5+0.1 \mathrm{~mm},-0.1+0.04 \mathrm{~mm} ;-+00.63 \mathrm{~mm},-0.2+0 \mathrm{~mm},-0.043+0 \mathrm{~mm}$, $-0.1+0.063 \mathrm{~mm}$. In the paper entitled "Structural and Physico-chemical Properties of Natural Zeolites: Clinoptilolite and Mordenite", the fractions of clinoptilolite with the particle size $\mathrm{ds}=0.355-0.5 \mathrm{~mm}$ and mordenite of $\mathrm{ds}=0.2-0.315 \mathrm{~mm}$ were chosen for examination (Korkuna et al. 2006). For studying the adsorption of arsenic (V) from a water solution onto a surfactant-modified zeolite, the authors Mendoza-Barron et al. (2011) used modified natural zeolite from the deposit located in San Luis Potosi, Mexico. The sample was ground and sieved to an average particle size of $0.42 \mathrm{~mm}(-20+30$ US mesh). Natural clinoptilolite zeolite from the Donje Jasinje deposit was used in three size classes: $-0.5 \mathrm{~mm}$, $-2+0.5 \mathrm{~mm}$ and $-5+2 \mathrm{~mm}$, in the paper "Kinetics and Thermodynamics Study of Copper

* Ph.D., *** B.Sc., Institute for Technology of Nuclear and Other Mineral Raw Materials, Belgrade, Serbia; e-mail: z.sekulic@itnms.ac.rs; m.kragovic@itnms.ac.rs; s.mihajlovic@itnms.ac.rs; b.ivosevic@itnms.ac.rs

** Professor, Ph.D., University of Belgrade, Faculty of Mining and Geology, Belgrade, Serbia; e-mail: kolonja@rgf.bg.ac.rs 
Ions Removal by Natural Clinoptilolite" (Ćurković et al. 2011). In their analysis "Adsorption of Chromate by Clinoptilolite Exchanged with Various Metal Cations", the authors Faghihian and Bowman (2005), used two different size fractions, 0.4-1.4 mm and 1.4-2.4 mm. In the paper entitled "Characterization of Water Absorption and Desorption Properties of Natural Zeolites in Ecuador", the authors Adriano et al. (2013) used the natural zeolites from the Policia deposit located in the Chongon-Colonche mountain range of the Guayas Province in Ecuador. The material obtained was classified according to its particle size as follows: Type I $(250-150 \mu \mathrm{m})$, Type II $(150-45 \mu \mathrm{m})$ and Type III $(<45 \mu \mathrm{m})$. The results of sorption experiments showed that type III $(<45 \mu \mathrm{m})$ had the largest diffusion coefficient with the following results: Type III (20.389E-08), Type II (11.930E-08), Type I (2.827E-08). Zhaohui Li et al. (2009) investigated the adsorption of chromates on natural zeolite by the modified surfactants. They used the following zeolite fractions: $3.6-4.8 \mathrm{~mm}, 1.4-2.4 \mathrm{~mm}$ and $<0.4 \mathrm{~mm}$. It was confirmed that adsorption of chromates increases with a decrease in zeolite particle size. Despite the fact that with an increase in particle size the adsorption of a specific pollutant decreases, it was also pointed out that larger particle size is required in order to achieve better hydraulic properties, and that, due to this fact, it is important to examine the effects of particle size on adsorption of the specific pollutant. Unlike most of the clay minerals and their property of swelling in water, zeolites have tighter three-dimensional crystal structure, and thus hydraulic properties that enable a wider range of applications in purifying contaminated water (Huggerty et al. 1994; Zhaohui Li et al. 1997; Sheng et al. 1997). Due to the inverse proportionality between the grain size and specific surface in the adsorption experiments with various contaminants in natural zeolite, it is necessary to test the effect of grain size on adsorption the specific contaminant (Lemic 2006).

If too low a cation exchange capacity (CEC) value of the ground class $-0.1+0 \mathrm{~mm}$ sample is obtained, after crushing the starting sample to the class $-3+0 \mathrm{~mm}$, the classification can be applied and then the class $-0.1+0 \mathrm{~mm}$ with satisfying CEC value can be separated. A higher $\mathrm{CEC}$ value can also be obtained from the rest of the classification, i.e. in the $+0.1 \mathrm{~mm}$ class, and grinding of that class will provide the desired quality of the class $-0.1+0 \mathrm{~mm}$. Therefore, testing the zeolite quality and its size class is important.

Since zeolite samples from the Igroš and Donje Jesenje deposits are used in this experimental work, several papers, already written on these zeolites will be listed first. For example, the paper by Tomašević-Čanović (2005) presents the results of zeolite analyses from three locations - the Igroš deposit, Zlatokop Vranjska Banja deposit, and Bala Mare Romania deposit. The samples were prepared below $0.2 \mathrm{~mm}$ in size. The author presented the chemical composition and CEC, and concluded, among other things, that the efficiency of lead leaching - apart from EDTA concentration and solid/liquid ratio - is influenced by the form of lead in zeolite. If a sufficiently large amount of EDTA is applied, most of the lead is extracted only from the sample Zlatokop - Vranjska Banja. With an increasing concentration of solids, the extraction efficiencies decrease - first for lead and aluminum and then for iron. For the sample Zlatokop - Vranjska Banja, the extraction efficiency of the tested cations is mainly a function of conditional stability constants and the stoichiometric ratio of applied 
EDTA to the total cation concentrations. The differences in extraction efficiencies from the three tested samples may be due to differences in the type of lead and iron present in the zeolite crystals. Radosavljevic-Mihajlovic et al. (2004) indicate that on the basis of complex mineralogical analyses of the Zlatokop-Vranjska Banja and Igroš deposits, these deposits are denoted as clinoptilolite- $\mathrm{Ca}$ type tuffs. Tibijaš et al. (2007), found that concentrations of clinoptilotite in volcaniclastic rocks of the Krapina area are extremely variable. In the samples of the Donje Jesenje quarry, the clinoptilolite content is more balanced. Large reserves of volcaniclastic make these layers profitable, and the characteristics of the raw material have to be taken into consideration in their use, i.e. the participation of zeolite in its chemical composition. Filipan et al. (2007) in their paper on the Donje Jesenje deposit, described a plant for crushing, separation and grinding (activation) of market products, next to the quarry. Clinoptilotite, as a dominant mineral, was found using mineralogical analysis before the appropriate application of zeolitic tuffs.

Based on the foregoing review of existing documentation and particularly a review of papers on zeolite from the Igroš and Donje Jesenje deposits, it can be said that the question of the size of zeolite range in terms of the method of obtaining - quality has not been discussed in detail. In order to determine this dependence, samples of run-of-mine zeolite were selected from the Igroš and Donje Jesenje deposits because it has been shown that there is a difference in their clinoptilolite content (Tibijaš et al. 2007). Testing was carried out on chemical composition and cation exchange capacity and XRPD analyses was performed on some size classes and starting samples.

\section{Experimental part}

\subsection{Preparation of Samples and Experiment Description}

Samples of natural zeolite from the Igroš (Serbia) and Donje Jesenje (Croatia) deposits were used for experimental work. The upper limit size value of the starting samples was 150 $\mathrm{mm}$. For the crushing process $100 \%$ of the samples used for further testing under laboratory conditions were of $-5 \mathrm{~mm}$ size class. A laboratory cone crusher and cylinder crusher were used in the experiments.

The experimental work included obtaining the specific classes from the starting sample of $100 \%-5 \mathrm{~mm}$. Therefore, sieving of the samples on laboratory screens with openings of $2.4 \mathrm{~mm}, 0.4 \mathrm{~mm}$, and $0.063 \mathrm{~mm}$, respectively, provided the following classes: $-5+2.4 \mathrm{~mm}$, $-2.4+0.4 \mathrm{~mm},-0.4+0.063 \mathrm{~mm}$, and $-0.063+0 \mathrm{~mm}$. These classes were tested using chemical analysis, mineralogical analysis, X-ray (XRPD) analysis and determining the cation exchange capacity (CEC). There may be other classes such as zeolite product range (see the references given), but it was decided that the testing be done on these classes, since the objective was to determine the trend of the distribution of zeolite minerals and CEC values. 


\subsection{Methods}

\section{Analysis of chemical composition}

The quantitative chemical composition of the starting zeolite sample, as well as the separated classes were determined using the Republic of Serbia standard SRPS B.F8.050 on an atomic spectrophotometer AAnalyst 300, Perkin Elmer. The samples were previously crushed to $-0.063+0 \mathrm{~mm}$.

\section{Determining the total cation exchange capacity}

The cation exchange capacity (CEC) was determined using the ion exchange method with $1 \mathrm{M} \mathrm{NH} \mathrm{NCl}_{4}$ as follows: $1 \mathrm{~g}$ of the sample was left for 24 hours in $100 \mathrm{ml}$ of ammonia suspension, at $\mathrm{pH} 7$, and periodically stirred. Upon completion of the cation exchange, the suspension was filtered and concentrations of changeable cations of $\mathrm{Ca}, \mathrm{Mg}, \mathrm{K}$ and $\mathrm{Na}$ were determined, resulting in the total CEC, calculated on meq/100 $\mathrm{g}$ of sample. Concentrations of changeable ions were determined using the atomic spectrophotometer AAnalyst 300, Perkin Elmer. Every measuring of the CEC was done three times, with the averaged values presented in this paper.

\section{X-ray powder diffraction method (XRPD)}

A "PHILIPS" PW-1710 X-ray diffractometer with curved graphite monochromator and scintillation counter was used for determining and monitoring the phase composition of the starting zeolite sample, as well as the separated classes. Samples were firstly prepared in a form of class $0.063+0 \mathrm{~mm}$.

\section{Results and discussion}

Grain size distribution of the zeolite samples used for testing from the Igroš and Donje Jesenje deposits are given in Table I.

Since the content of finer class $-0.063+0 \mathrm{~mm}$ (Table 1 ), obtained by crushing of the sample from Donje Jasenje, is higher $(9.75 \%)$ relative to the Igroš $-0.063+0 \mathrm{~mm}$ sample

Table 1. Grain size distribution of the used zeolite samples from the Igroš and Donje Jesenje deposits

Tabela 1. Skład ziarnowy badanych próbek zeolitów ze złóż Igroši Donje Jesenje

\begin{tabular}{|c|c|c|}
\hline Size classes [mm] & Content [\%] Igroš & Content [\%] Donje Jesenje \\
\hline Starting sample & 100.00 & 100.00 \\
\hline$-5+2.4$ & 13.90 & 11.10 \\
\hline$-2.4+0.4$ & 60.20 & 61.05 \\
\hline$-0.4+0.063$ & 21.05 & 18.10 \\
\hline$-0.063+0$ & 4.85 & 9.75 \\
\hline
\end{tabular}


(4.85\%), it can be said that these samples are different regarding the physical properties of the impurities present, which has an effect on the crushing results. It can also be said that the sample with a higher content of finer $-0.063+0 \mathrm{~mm}$ class (Donje Jesenje) has more minerals present which are softer and more convenient for crushing.

The results of the chemical composition analysis of the starting samples and samples of some size classes of natural zeolite are presented in Table 2.

Table 2. Chemical composition of zeolite from the Igroš and Donje Jesenje deposits

Tabela 2. Skład chemiczny zeolitów ze złóż Igroš i Donje Jesenje

\begin{tabular}{|c|c|c|c|c|c|c|c|c|c|}
\hline \multirow{2}{*}{ Sample } & \multicolumn{9}{|c|}{ Content [\%] } \\
\hline & $\mathrm{SiO}_{2}$ & $\mathrm{Al}_{2} \mathrm{O}_{3}$ & $\mathrm{Fe}_{2} \mathrm{O}_{3}$ & $\mathrm{CaO}$ & $\mathrm{MgO}$ & $\mathrm{K}_{2} \mathrm{O}$ & $\mathrm{Na}_{2} \mathrm{O}$ & LoI & Total \\
\hline \multicolumn{10}{|c|}{ Igroš } \\
\hline Starting & 62.25 & 13.50 & 2.76 & 6.41 & 1.22 & 1.20 & 1.24 & 10.85 & 99.43 \\
\hline$-5+2.4 \mathrm{~mm}$ & 65.11 & 9.33 & 2.59 & 4.89 & 0.89 & 2.01 & 3.05 & 11.45 & 99.32 \\
\hline$-2.4+0.4 \mathrm{~mm}$ & 61.85 & 13.99 & 2.76 & 6.65 & 1.26 & 1.07 & 0.87 & 11.04 & 99.49 \\
\hline$-0.4+0.063 \mathrm{~mm}$ & 61.64 & 14.78 & 2.90 & 6.62 & 1.30 & 1.08 & 1.21 & 9.96 & 99.49 \\
\hline$-0.063+0 \mathrm{~mm}$ & 61.74 & 13.89 & 2.80 & 6.90 & 1.31 & 1.09 & 0.85 & 10.74 & 99.34 \\
\hline \multirow{2}{*}{ Sample } & \multicolumn{9}{|c|}{ Content $[\%]$} \\
\hline & $\mathrm{SiO}_{2}$ & $\mathrm{Al}_{2} \mathrm{O}_{3}$ & $\mathrm{Fe}_{2} \mathrm{O}_{3}$ & $\mathrm{CaO}$ & $\mathrm{MgO}$ & $\mathrm{K}_{2} \mathrm{O}$ & $\mathrm{Na}_{2} \mathrm{O}$ & LOI & Total \\
\hline \multicolumn{10}{|c|}{ Donje Jesenje } \\
\hline Starting & 69.45 & 12.63 & 1.64 & 3.78 & 0.42 & 2.07 & 2.99 & 6.58 & 99.56 \\
\hline$-5+2.4 \mathrm{~mm}$ & 77.14 & 8.68 & 1.096 & 2.38 & 1.08 & 1.12 & 0.836 & 6.99 & 99.32 \\
\hline$-2.4+0.4 \mathrm{~mm}$ & 68.51 & 12.97 & 1.63 & 4.01 & 0.31 & 2.20 & 3.35 & 6.51 & 99.49 \\
\hline$-0.4+0.063 \mathrm{~mm}$ & 68.00 & 13.09 & 1.92 & 4.20 & 0.40 & 2.14 & 3.12 & 6.45 & 99.32 \\
\hline$-0.063+0 \mathrm{~mm}$ & 69.24 & 12.66 & 1.84 & 3.15 & 0.39 & 2.22 & 2.97 & 6.85 & 99.32 \\
\hline
\end{tabular}

The results of chemical analyses of the starting samples (Table 2) show that there is a difference in the content of some oxides. Only the $\mathrm{Al}_{2} \mathrm{O}_{3}$ content is similar (Igroš $13.5 \%$, Donje Jesenje $12.63 \%$ ). $\mathrm{CaO}$ content in the starting zeolite sample from the Igroš deposit is $6.41 \%$, and in the Donje Jesenje deposit sample it is $3.78 \%$. CaO content in the finest Igroš fraction is $6.90 \%$, and in the Donje Jesenje zeolite $3.15 \%$. Higher $\mathrm{CaO}$ content usually indicates a higher content of Ca-carbonates. A higher annealing mass loss of $10.85 \%$ in the Igroš zeolite (comparadet to $6.58 \%$ in the Donje Jesenje zeolite) confirms that $\mathrm{SiO}_{2}$ content is $69.45 \%$ in the Donje Jesenje sample, while in the Igroš sample it amounts to $62.25 \%$, indicating the possibility of a higher content of quartz and/or other silicate impurities.

The following comments can be made on the chemical composition of the starting samples, $100 \%$ of which were crushed to size $-0.063+0 \mathrm{~mm}$, and obtained by sieving the crushed sample: 
- In the Igroš sample, differences in the content of any analyzed oxide are very small. For example, $\mathrm{SiO}_{2}$ content of the starting sample is $62.25 \%$, while in the sample obtained by sieving to $0.063 \mathrm{~mm}$, it is $61.74 \%$. $\mathrm{CaO}$ content in the starting Igroš sample is $6.41 \%$, while in the sieved sample, it amounts to $6.90 \%$.

- In the case of the Donje Jesenje sample, there are no differences in the chemical composition of the starting sample and the sample $100 \%$ crushed to size $-0.063 \mathrm{~mm}$. $\mathrm{SiO}_{2}$ content of the starting sample, is $69.45 \%$, and the sample, obtained by sieving to $0.063 \mathrm{~mm}$, totals $69.24 \%$.

The results of the analysis on the chemical composition the size classes, obtained from the sample Donje Jesenje, show the highest $\mathrm{SiO}_{2}$ content in the class $-5+2.4 \mathrm{~mm}$. This is around $7 \%$ higher than in all other classes, in which $\mathrm{SiO}_{2}$ content is in the range from $69.24 \%$ to $69.45 \%$. This indicates the highest content of quartz is found in the Donje Jesenje sample. The increased $\mathrm{MgO}$ content was also observed in the class $-5+2.4 \mathrm{~mm}$ at $1.8 \%$, while in the other classes it ranged from $0.31 \%$ to $0.42 \%$. This indicates the possible presence of magnesium silicate (impurity), so it can be said that the quality of the $-5+2.4 \mathrm{~mm}$ class is lower than the quality of other analyzed classes.

The total content of oxides $\mathrm{CaO}+\mathrm{MgO}+\mathrm{Na}_{2} \mathrm{O}+\mathrm{K}_{2} \mathrm{O}$, calculated on the basis of the results presented in Table 2, and the values of total cation exchange capacity (CEC) are presented in Table 3.

Table 3. Total content of oxides $\mathrm{CaO}+\mathrm{MgO}+\mathrm{K}_{2} \mathrm{O}+\mathrm{Na}_{2} \mathrm{O}$ and total CEC in zeolite samples from Igroš deposits and Donje Jesenje deposits

Tabela 3. Łączna zawartość tlenków $\mathrm{CaO}+\mathrm{MgO}+\mathrm{K}_{2} \mathrm{O}+\mathrm{Na}_{2} \mathrm{O}$ oraz łączna pojemność wymiany kationowej CEC zeolitów ze złóż Igroš i Donje Jesenje

\begin{tabular}{|c|c|c|c|c|}
\hline \multirow{2}{*}{$\begin{array}{c}\text { Size class } \\
{[\mathrm{mm}]}\end{array}$} & \multicolumn{2}{|c|}{ Content of $\mathrm{CaO}+\mathrm{MgO}+\mathrm{K}_{2} \mathrm{O}+\mathrm{Na}_{2} \mathrm{O}[\%]$} & \multicolumn{2}{|c|}{ CEC [meq/100 g] } \\
\cline { 2 - 5 } & Igroš & Donje Jesenje & Igroš & Donje Jesenje \\
\hline Starting & 10.07 & 9.20 & 139.09 & 115.82 \\
\hline$-5+2.4$ & 10.84 & 5.42 & 161.25 & 128.91 \\
\hline$-2.4+0.4$ & 9.85 & 9.87 & 127.08 & 92.21 \\
\hline$-0.4+0.063$ & 10.21 & 9.46 & 159.45 & 163.97 \\
\hline$-0.063+0$ & 10.15 & 8.73 & 136.23 & $159.4-$ \\
\hline
\end{tabular}

Based on the results by size classes (Table 3) for the sum of oxides used in the CEC calculation and the values of CEC, it can be seen that the CEC is the highest in the $-5+2.4 \mathrm{~mm}$ class $(161.25 \mathrm{meq} / \mathrm{g})$ for the Igroš zeolite, and the CEC is the highest $(163.97 \mathrm{meq} / \mathrm{g})$ in the Donje Jesenje zeolite for the class $-0,4+0,063 \mathrm{~mm}$. Content of oxides of $10.84 \%$ is the highest in the class $-5+2.4 \mathrm{~mm}$ of the Igroš zeolite, while in the Donje Jesenje zeolite, the highest content of oxides was found in the classes $-0.4+0.063 \mathrm{~mm}$ and $-0.063+0 \mathrm{~mm}$. This indicates that the content of impurities in the Igroš zeolite is higher in finer classes, while in the Donje Jesenje zeolite, it is higher in coarse classes. 
The results of X-ray diffraction analysis on the natural zeolite starting sample and size classes are given in Fig. 1 and Fig. 2, and mineralogical description is presented in Table 4.

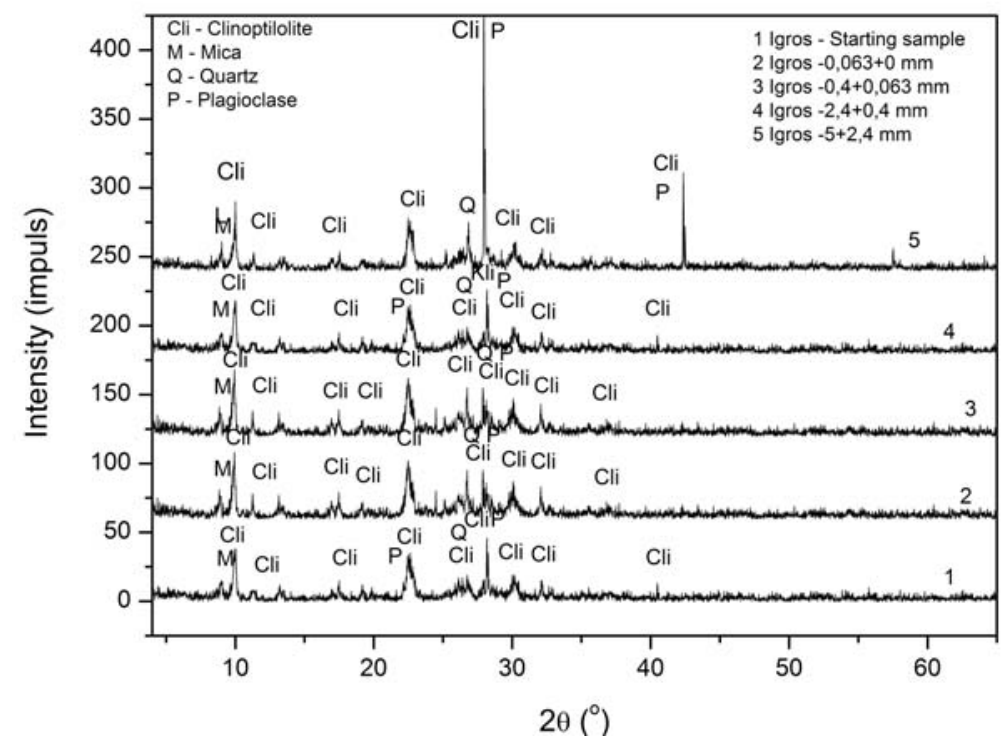

Fig. 1. Powder diffractogram of Igroš samples

Rys. 1. Dyfraktogram proszkowy ze złoża Igroš

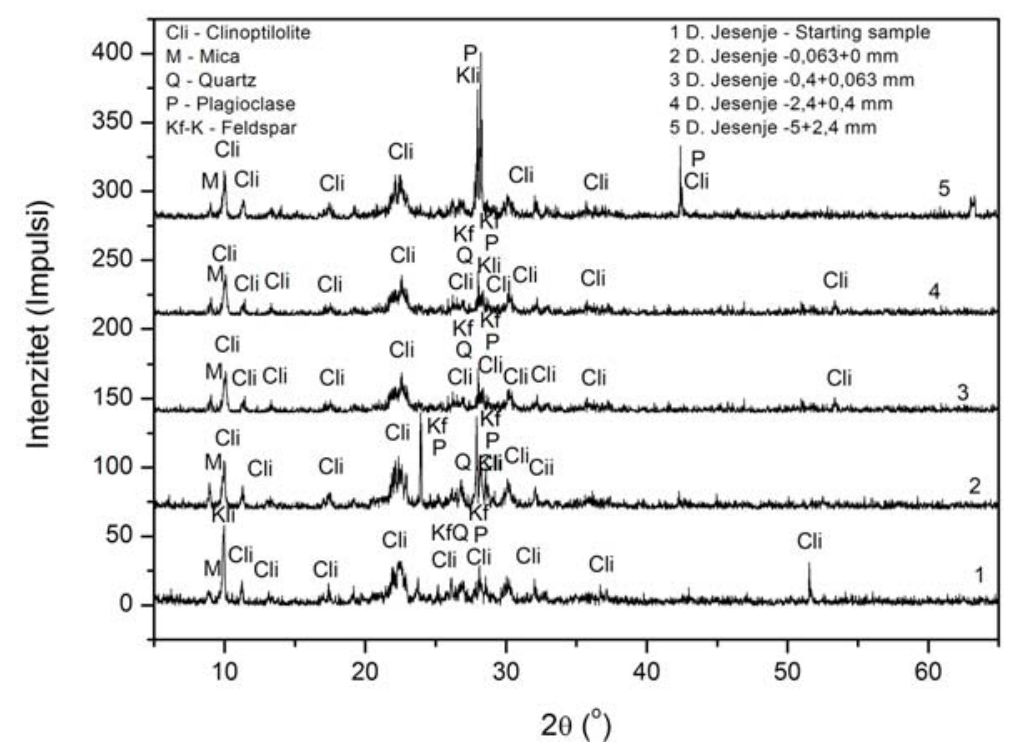

Fig. 2. Powder diffractogram of Donje Jesenje samples

Rys. 2. Dyfraktogram proszkowy ze złoża Donje Jesenje 
Table 4. Collective review the main results of zeolite analyses from the Igroš and Donje Jesenje deposits

Tabela 4. Zestawienie zbiorcze wyników badań zeolitów ze złóż Igroš i Donje Jesenje

\begin{tabular}{|c|c|c|c|}
\hline \multicolumn{4}{|r|}{ Results } \\
\hline Sample & $\begin{array}{c}\text { According to } \\
\text { content of } \mathrm{CaO}+ \\
+\mathrm{MgO}+\mathrm{K}_{2} \mathrm{O}+ \\
+\mathrm{Na}_{2} \mathrm{O}+\mathrm{K}_{2} \mathrm{O} \\
{[\%]}\end{array}$ & $\begin{array}{l}\text { According } \\
\text { to CEC, } \\
{[\mathrm{meq} / 100 \mathrm{~g}]}\end{array}$ & According to $\mathrm{XRD}$ \\
\hline \multicolumn{4}{|r|}{ Igroš } \\
\hline Starting & 10.07 & 139.09 & \multirow{3}{*}{$\begin{array}{l}\text { The following minerals were found: zeolites of HEU type, } \\
\text { quartz, micas, plagioclases, volcanic glass. Content of } \\
\text { zeolites was the highest, while content of other minerals was } \\
\text { lower. The degree of crystallinity was very low. }\end{array}$} \\
\hline$-5+2.4$ & 10.84 & 161.25 & \\
\hline$-2.4+0.4$ & 9.85 & 127.08 & \\
\hline$-0.4+0.063$ & 10.21 & 159.45 & $\begin{array}{l}\text { Content of zeolite was higher compared to the previous } \\
\text { sample. The degree of crystallinity was very low. }\end{array}$ \\
\hline$-0.063+0$ & 10.15 & 136.23 & $\begin{array}{l}\text { As in the previous sample, zeolites of HEU type are } \\
\text { somewhat higher compared to the first two samples. } \\
\text { The degree of crystallinity was very low. }\end{array}$ \\
\hline \multicolumn{4}{|r|}{ Donje Jesenje } \\
\hline Starting & 9.20 & 115.82 & $\begin{array}{l}\text { The following minerals were found: zeolite of HEU type, } \\
\text { quartz, micas, plagioclases, K-FELDSPAR, volcanic glass. } \\
\text { Content of zeolites was the highest, while content of other } \\
\text { minerals was lower. The degree of crystallinity was very low. }\end{array}$ \\
\hline$-5+2.4$ & 5.42 & 128.91 & $\begin{array}{l}\text { The following minerals were found: zeolites of HEU type, } \\
\text { quartz, micas, plagioclases, volcanic glass. Content of } \\
\text { zeolites was the highest, while content of other minerals was } \\
\text { lower. The degree of crystallinity was very low. }\end{array}$ \\
\hline$-2.4+0.4$ & 9.87 & 92.21 & $\begin{array}{l}\text { Content of zeolites was somewhat lower compared to the } \\
\text { previous sample, while feldspar content was somewhat } \\
\text { higher. The degree of crystallinity was very low. }\end{array}$ \\
\hline$-0.4+0.063$ & 9.46 & 163.97 & $\begin{array}{l}\text { Quantitative interrelation of minerals was the same as in the } \\
\text { previous sample. The degree of crystallinity was very low. }\end{array}$ \\
\hline$-0.063+0$ & 8.73 & 159.40 & $\begin{array}{l}\text { The difference compared to the two previous samples was } \\
\text { in lower zeolite content, while feldspar content was higher. } \\
\text { The degree of crystallinity was very low. }\end{array}$ \\
\hline
\end{tabular}

Based on the results of X-ray diffractogram analysis (Fig. 1 and 2), it is apparent that the dominant zeolite mineral in both samples of zeolite is clinoptilotite. In the sample from the Igroš deposit, the impurities are quartz, mica, and plagioclase, while in the Donje Jesenje sample, in addition to the above impurities, there is also feldspar.

Collective review of the obtained test results from the Igroš and Donje Jesenje deposits is presented in Table IV. These results show that the highest content of oxides $(\mathrm{CaO}+\mathrm{MgO}+$ $+\mathrm{Na}_{2} \mathrm{O}+\mathrm{K}_{2} \mathrm{O}$ ) in the Igroš zeolite samples was found in the class $-5+2.4 \mathrm{~mm}-$ at $10.84 \%$. 
In the Donje Jesenje deposit samples, the highest oxide content $\left(\mathrm{CaO}+\mathrm{MgO}+\mathrm{Na}_{2} \mathrm{O}+\mathrm{K}_{2} \mathrm{O}\right)$ was found in the classes $-2.4+0.4 \mathrm{~mm}(9.87 \%)$ and $-0.4+0.063 \mathrm{~mm}(8.73 \%)$.

Considering these results, the CEC value of zeolite from the Donje Jesenje deposit is the highest in the size class $-5+2.4 \mathrm{~mm}$ at $161.25 \mathrm{meq} / 100 \mathrm{~g}$, while in the Donje Jesenje deposit, the highest CEC was found in the class $0.4+0.063 \mathrm{~mm}$ at $163.97 \mathrm{meq} / 100 \mathrm{~g}$. Since the content of useful oxides in the class $-2.4+0.063 \mathrm{~mm}$ for Donje Jesenje does not correspond to by the highest CEC, which is $92.21 \mathrm{meq} / 100 \mathrm{~g}$, the explanation could be in the result of XRD analyses which shows that feldspar mineral content is higher in this class than in the other classes. If it is necessary to obtain the class $-0.063+0 \mathrm{~mm}$ in the case of the Igros deposit zeolite, the starting sample has to be crushed since the CEC of the starting sample and the CEC of the class $-0.063+0 \mathrm{~mm}$ are slightly different $(139.09$ and $136.23 \mathrm{meq} / 100 \mathrm{~g})$. This class in the case of zeolite from the Donje Jesenje deposits should be better produced by firstly classifyng the starting sample at $0.4 \mathrm{~mm}$, and then crushing to $-0.063+0 \mathrm{~mm}$ since the CEC of the class $-0.4+0 \mathrm{~mm}$ is $163.97 \mathrm{meq} / 100 \mathrm{~g}$, in class $-0.063+0 \mathrm{~mm} 159.4 \mathrm{meq} / 100 \mathrm{~g}$, while in the starting sample it is $115.82 \mathrm{meq} / 100 \mathrm{~g}$.

Results of testing the significance of size classes of zeolite range have showed that the adsorption capacity is not the same when it comes to coarser or finer fractions. For example, in Ćurković et al. (2011) the parabolic diffusion model is a well described process across all examined range of time and shows that the calculated diffusion coefficient increases with temperature, this increase is more visible at coarser particle sizes which assume diffusion through zeolite particle as the main mass transfer mechanism. Next, in Faghihian and Bowman (2005) two different size fractions, 14-40 (0.4-1.4 mm) and 8-14 (1.4-2.4 mm) were used in the experiments, chromate retention was always significantly higher on the exchanged 14-40 samples than on the 8-14 samples. This pattern was likely due to the slightly higher exchange fractions for the 14-40 samples, and higher reaction rate in the finer 14-40 samples. Since the adsorption capacity of the sample was 0.360 meqg -1 zeolite (14-40), the exchanged form may be used for adsorption and immobilization of chromate. Next, Adriano et al. (2013): using natural zeolites, $250-150 \mu \mathrm{m}, 150-45 \mu \mathrm{m}$, and $<45 \mu \mathrm{m}$, the results of sorption experiments showed that $<45 \mu \mathrm{m}$ had the highest diffusion coefficient, resulting in Type $<45 \mu \mathrm{m}(20.389 \mathrm{E}-08)$, Type $150-45 \mu \mathrm{m}$ (11.930E-08), and Type $250-150 \mu \mathrm{m}$ (2.827E-08). In Zhaohui Li et al. (2009) it was confirmed that adsorption of chromates increases with a decrease in zeolite particle size, despite the fact that with the increase in particle size the adsorption of specific pollutant decreases, it was also pointed out that higher particle size is required in order to achieve better hydraulic properties and due to this, it is important to investigate the effects of particle size on adsorption of the specific pollutant. These tests were performed on classes (asortimen) used in varying fields ranging from environmental agricultural to building materials production. The test show that the consequence of higher or lower adsorption capacity is not only coarseness, but also distribution of zeolite minerals per the size classes. The significance of these results from a practical point of view is two-fold because the distribution of zeolite minerals per size classes determines the application and method of obtaining these product ranges. 


\section{Conclusion}

In order to test the results of natural zeolite samples from the Igroš (Serbia) and Donje Jesenje deposits (Croatia), the starting zeolite samples were crushed and classified according to the size classes $-5+2.4 \mathrm{~mm},-2.4+0.4 \mathrm{~mm},-0.4+0.063 \mathrm{~mm}$, and $-0.063+0 \mathrm{~mm}$. Analyzing each of these size classes it was found that there is a difference in the quality of some individual size classes of each deposit. For example, the CEC for the size class $-5+2.4 \mathrm{~mm}$, obtained from the Igroš sample, was $161.25 \mathrm{meq} / 100 \mathrm{~g}$, while in class $-0.063+0 \mathrm{~mm}$ from the same sample the CEC was $136.23 \mathrm{meq} / 100 \mathrm{~g}$.

There is also a difference in the quality of some size classes compared to the results of the same size classes from the Igroš and Donje Jesenje deposits. Specifically, the CEC in the Igroš zeolite is the highest in the size class $-5+2.5 \mathrm{~mm}$ at $161.25 \mathrm{meq} / 100 \mathrm{~g}$, while the highest CEC in the Donje Jesenje deposit was found in the class $-0.4+0.063 \mathrm{~mm}$ at $163.97 \mathrm{meq} / 100 \mathrm{~g}$.

XRD analyses showed that the mineral content is not the same between the Igroš sample and the Donje Jesenje sample. In the Igroš sample, higher zeolite mineral content was observed in coarse size classes. In the sample from the Donje Jesenje deposit, feldspar was found in the class $-0.063+0 \mathrm{~mm}$.

The above results indicate that it is necessary to use various methods for obtaining the required zeolite quality depending on the distribution of the mineral components in the starting zeolite sample.

Acknowledgments: This paper is the result of analyses under Projects 034013 and 172018, funded by the Ministry of Education and Science of the Republic of Serbia from 2011-2014

\section{REFERENCES}

Adriano et al. 2013 - Adriano, A., Soriano, G. and Duque, J., 2013. Characterization of Water Absorption and Desorption Properties of Natural Zeolites in Ecuador, Fifth International Symposium on Energy, Puerto Rico Energy Center-Laccei, Puerto Rico, pp. 1- 8.

Ćurković et al. 2011 - Ćurković, L., Trgo, M., Rožić, M., Medvidović, N.V., 2011. Kinetics and Thermodynamics Study of Copper Ions Removal by Natural Clinoptilolite, Indian Journal of Chemical Technology 18(2), pp. 137-144.

Faghihian, H. and Bowman, R.S., 2005. Adsorption of Chromate by Clinoptilolite Exchanged with Various Metal Cations, Water Research 39, 6, pp. 1099-1104.

Filipan et al. 2007 - Filipan, T., Tišma, S., Farkaš, A., Butorac, A. and Cerjan-Stefanović, Š., 2007. Production, Properties and Application of Zeolitic Tuff (Cp) and Preparation of "SPS" from Donje Jesenje, Natural Zeolitic Tuff from Croatia in Environmental Protection (Edited by: Filipan, Tugomir; Tišma, Sanja; Farkaš, Anamarija), Zagreb: Institute of International Relations, pp. 53-83.

Huggerty, G.M. and Bowman, R.S., 1994. Sorption of Inorganic Anions by Organo-Zeolites, Environmental Science and Technology 28, 3, pp. 452-458.

Korkuna et al. 2004 - Korkuna, O., Leboda, R., Skubiszewska-Zięba, J., Vrublevs‘ka, T., Gun'ko, V.M. and Ryczkowski, J. 2006. Structural and Physicochemical Properties of Natural Zeolites: Clinoptilolite and Mordenite, Microporous and Mesoporous Materials 87, pp. 243-254. 
Lemić, J., 2006. Modified Aluminosilicate Minerals as Adsorbents in Treatment of Contaminated Waters, Doctoral Thesis, Belgrade, Institute for Technology of Nuclear and Other Mineral Raw Materials, p. 99.

Mendoza-Barron et al. 2004 - Mendoza-Barron, J., Jacobo-Azuara, A., Leyva-Ramos, R., Berber-Mendoza, M.S., Guerrero-Coronado, R.M., Fuentes-Rubio L. and Martínez-Rosales, M., 2011. Adsorption of Arsenic (V) from a Water Solution onto a Surfactant-modified Zeolite, Adsorption 17, pp. 489-496.

Radosavljevic-Mihajlovic et al. 2004 - Radosavljevic-Mihajlovic, A., Stojanovic, J., Kasic, V., Dakovic, A. and Tesmanovic, LJ., 2004. Comparative Mineralogical Qualities of Serbian Zeolitic Tuff Deposits, Proceedings of the $36^{\text {th }}$ International October Conference on Mining and Metallurgy, Bor, Serbia, pp.22-28.

Sheng, G. and Boyd, S.A., 1998. Relation of Water and Neutral Organic Compounds in the Interlayers of Mixed $\mathrm{Ca}$ /trimethylphenylammonium-smectites, Clays and Clay Minerals 46, pp. 10-17.

Tibljaš, D. and Šćavničar, S., 2007. Deposits of Zeolitic Tuffs in Krapina Area, Natural Zeolite Tuff from Croatia in Environmental Protection (Edited by: Filipan, Tugomir; Tišma, Sanja; Farkaš, Anamarija), Zagreb: Institute of International Relations, pp.13-25.

Tomašević-Čanović, M., 2005. Purification of Natural Zeolite-clinoptilolite for Medical Application - Extraction of Lead, Journal of the Serbian Chemical Society 70 (11), pp.1335-1345.

Zhaohui, L. and Honga, H., 2009. Retardation of Chromate through Packed Columns of Surfactant - Modified Zeolite, Journal of Hazardous Materials 162, 1487-1493.

Zhaohui L. and Bowman, R.S., 1997. Counterion Effects on the Sorption of Cationic Surfactant and Chromate on Natural Clinoptilolite, Enviromental Science and Technology 31, 8, pp. 2407-2412.

\section{JAKOŚĆ ZEOLITÓW JAKO FUNKCJA ICH UZIARNIENIA}

\section{Słowa kluczowe}

zeolit naturalny, złoża Igroš i Donje Jesenje, klasy ziarnowe, pojemność wymiany kationowej

\section{Streszczenie}

Badanie parametrów jakościowych zeolitów ze złóż Igroš i Donje Jesenje zostało przeprowadzone odrębnie dla różnych klas ziarnowych. Celem tych badań było wskazanie znaczenia selekcji i procedury przygotowania surowca na parametry jakościowe poszczególnych klas ziarnowych, co ma skutkować osiagnięciem wymaganych parametrów jakościowych przez otrzymywany zestaw produktów zeolitowych. Rezultaty badań wskazują, że zeolity ze złóż Igroš i Donje Jesenje różnią się pod względem parametrów jakościowych w przypadku niektórych klas ziarnowych. Podczas gdy próbka zeolitu ze złoża Igroš wykazuje lepsze parametry jakościowe w przypadku klas drobniejszych, to w przypadku próbki ze złoża Donje Jesenje lepesze parametry jakościowe wykazuje klasa ziarnowa $-2,4+0,4 \mathrm{~mm}$. Pojemność wymiany kationowej (CEC) zeolitu ze złoża Igroš jest najwyższa $161,25 \mathrm{meq} / 100 \mathrm{~g}$ - dla klasy ziarnowej $-5+2,4 \mathrm{~mm}$, podczas gdy w przypadku zeolitu ze złoża Donje Jesenje najwyższa wartość tego parametru - 163,97 meq/100 g - była stwierdzona dla klasy $-0,4+0,063 \mathrm{~mm}$. Przeprowadzone badania rentgenograficzne wykazały, że skład mineralny próbek zeolitów ze złóż Igroš i Donje Jesenje znacznie się różni: wyższy udział minerałów grupy zeolitów był zaobserwowany w grubszych klasach ziarnowych surowca ze złoża Igroš, podczas gdy w surowcu ze złoża Donje Jasenje wyższy udział zeolitów był stwierdzony dla klasy najdrobniejszej $-0,063+0 \mathrm{~mm}$, przy współobecności skaleni i niewielkim udziale klinoptylolitu. Rezultaty badań wskazują, że niezbędne jest w przypadku tych materiałów zastosowanie metod klasyfikacji ziarnowej i otrzymy- 
wania najdrobniejszych klas ziarnowych, by możliwe było otrzymanie zestawu produktów zeolitowych o wymaganych parametrach jakościowych.

\title{
QUALITY OF ZEOLITE IN THE FUNCTION OF SIZE CLASS
}

\author{
Key words
}

Natural zeolite, Igroš and Donje Jesenje deposits, size classes, cationic exchange capacity

\section{Abstract}

Testing of the quality of zeolite from the Igroš and Donje Jesenje deposits was carried out by size classes. The objective of the testing was to point out the importance of the selection of the preparation procedure in determining the quality of individual size classes provide the required quality of zeolite product range. The results indicate that the Igroš and Donje Jesenje zeolite deposits differ by the quality of some size classes. While the Igroš sample has better quality of fine size classes, in the case of the Donje Jesenje deposit, the sample size class $-2.4+0.4 \mathrm{~mm}$ indicates better quality. Specifically, the cation exchange capacity (CEC) of the Igroš zeolite is the highest at $161.25 \mathrm{meq} / 100 \mathrm{~g}$ in the case of size class $-5+2.4 \mathrm{~mm}$, while the highest CEC of zeolite from the Donje Jesenje deposits, $163.97 \mathrm{meq} / 100 \mathrm{~g}$, was found for the class $-0.4+0.063 \mathrm{~mm}$. The results of XRD analyses showed that the mineral content was distributed differently in the Igroš sample relative to the Donje Jesenje sample. The XRPD results showed a higher content of zeolite minerals in coarse size classes of the Igroš sample, while in the Donje Jasenje zeolite, the size class of $-0.063+0 \mathrm{~mm}$, and the presence of feldspar and lower content of clinoptilotite were observed. These results indicate that it is necessary to use the methods for obtaining finer size classes and classification in order to achieve the required quality of zeolite product range. 